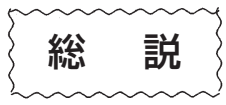

\title{
アコヤガイ赤変病
}

\author{
山下浩史* ・ 小田原和史
}

(2017年 1 月20日受付)

\section{Akoya Oyster Disease}

\author{
Hirofumi Yamashita* and Kazushi Odawara \\ Fisheries Research Center, Ehime Research Institute of Agriculture, Forestry and \\ Fisheries Shitaba, Ehime 798-0104, Japan
}

(Received January 20, 2017)

\begin{abstract}
Since 1996, mass mortalities of cultured Japanese pearl oyster Pinctada fucata martensii have been occurring in western Japan. Mortalities are accompanied with reddish-brown discoloration of the soft body, especially the adductor muscle of oysters. This disease was named "akoya oyster disease (AOD)". However, the cause of the disease is still unidentified. As a control strategy of this disease, selective breeding of pearl oysters resistant to AOD has been conducted in several public institutes and private groups. The recent decline in outbreaks of AOD can be attributed, in part, to the introduction of selectively bred oysters that are resistant to this disease.
\end{abstract}

1994年に西日本の一部の真珠貝養殖場で軟体部の赤変 化を伴う死亡が発生し，その後1996年には西日本の主要 真珠貝養殖場で同様の症状を示す大量死が顕在化した。 その死亡率は最大 $70 \%$ に達し, さらに本大量死はこの後 毎年続けて発生したため, 本邦の真珠貝養殖業は壊滅的 な打撃を受けた。罹病したアコヤガイは，夏季から秋季 にかけて閉殼筋を含む軟体部が赤色から茶褐色に着色し, その後急激に衰弱して死亡する。一部生残した貝は, 水 温が低下する冬季には着色も薄れ回復に向かう。本病の 被害規模は極めて大きく, 本病発生以前の1993年と本病 発生後の1999年を比較すると, 全国の真珠生産量は 78.2 t から $24.6 \mathrm{t}(33.8 \%)$ に減少, 真珠母貝の生産量は 9,460 t から 2,403 t (25.4\%) に減少し, その被害額は 数百億円規模に達し, 真珠養殖業界は危機的状況に陥る こととなった（森実ら，2001）。

これらの被害を受けて, 本病の原因探索が精力的にお こなわれた。当初, 魚類の寄生虫駆除に用いられるホル マリン, アコヤウイルス (Miyazaki et al., 1999), マリ ンビルナウイルス, 餌料環境の悪化など諸説が原因とし

愛媛県農林水産研究所水産研究センター

* Corresponding author

E-mail: yamashita-hirofumi@pref.ehime.lg.jp
て報告されたが, 研究者間のコンセンサスは得られな かった（室賀ら，1999）。水産庁養殖研究所（当時）を 中心として関係各県がアコヤガイ赤変病研究会を設立し, 様々な検討をおこなった結果, “感染性疾病であることが 強く示唆される”というコンセンサスを得ているが，そ の原因体の特定には至っていない。

\section{病 理 所 見}

特徵的な肉眼所見は, 閉殼筋を含む軟体部の赤変化お よび委縮が挙げられる。また, 赤変化が顕著な個体では 心房の肥大も観察される (Fig. 1a, b)。組織学的に最も 普遍的な病変は, 外套膜の結合組織に見られる。正常な 外套膜の結合組織は, 組織切片上では一様に透明感があ り疎繊維性で, ヘマトキシリンでわずかに染まり，その 所々に瀻維芽細胞が散在している。また, 外套神経環に 隣接する外套動脈は, 内皮細胞でなめらかに縁取られ, その管腔も広い (Fig. 2a)。一方, 異常貝の結合組織で は，エオシンによく染まる繊維成分の多い結合組織，あ るいは浸潤してきたと思われる多数の血球が観察される。 また, 外套神経環に隣接する外套動脈の血管壁は断裂し, 病変の著しい個体では管構造が不明瞭になっている（Fig. $2 b)$ 。閉殼筋にも特徵的な病変が確認される。正常な閉 

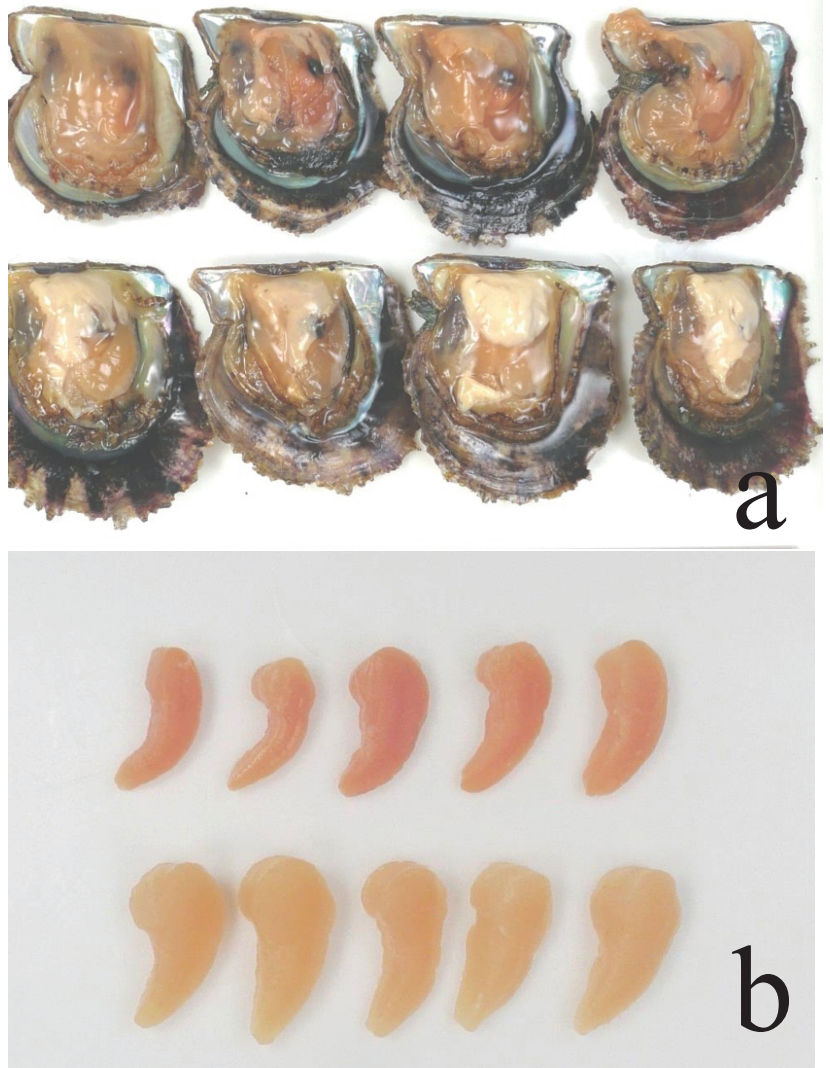

Fig. 1. a: Gross view of pearl oysters with one side of the shell removed. The upper and lower rows represent diseased and normal oysters, respectively. b: Adductor muscles of diseased oysters (upper row) and normal oysters (lower row).

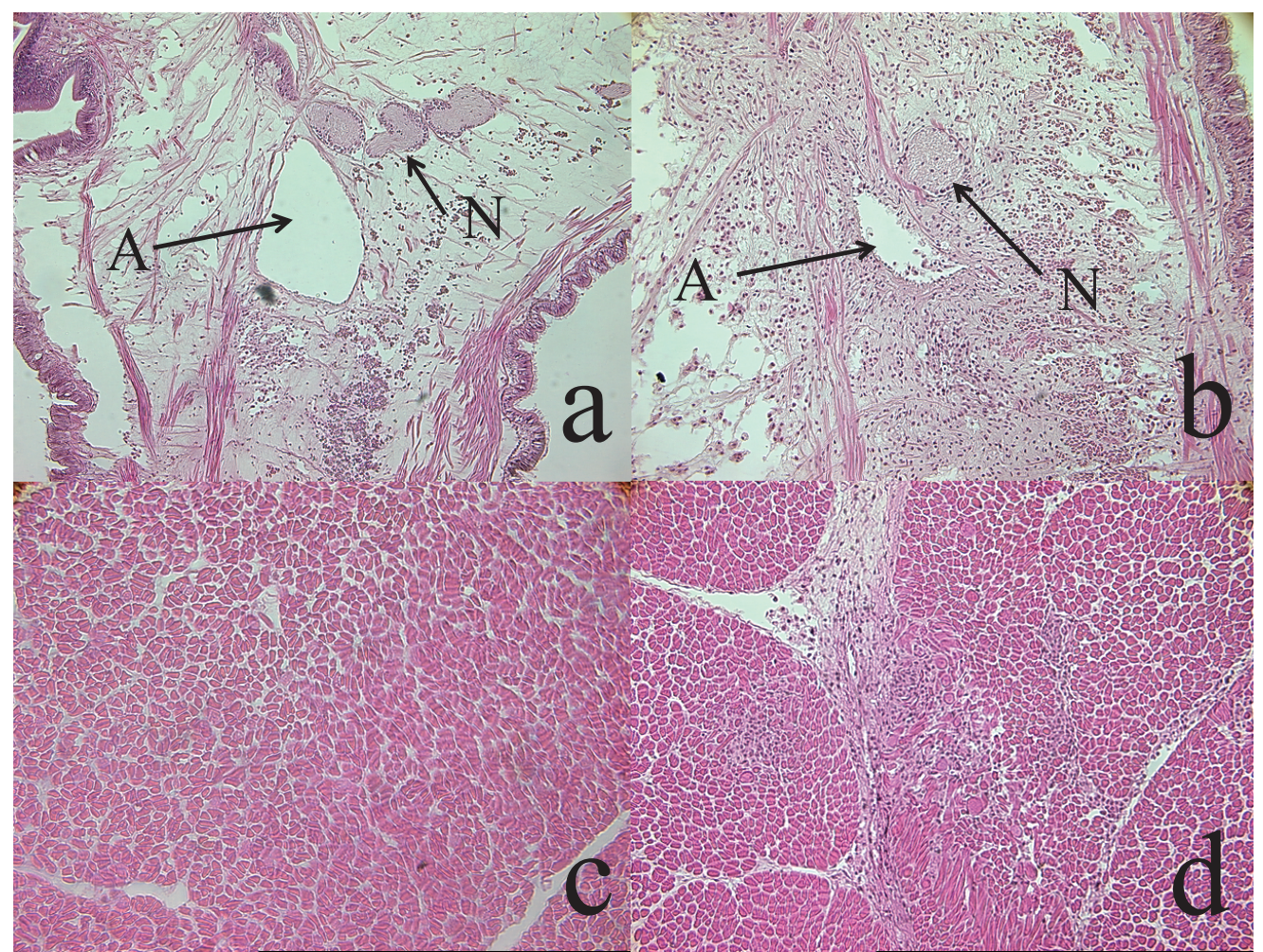

Fig. 2. a: normal mantle, b: abnormal mantle, c: normal adductor muscle, $\mathrm{d}$ : abnormal adductor muscle. $\mathrm{A}$, mantle arteria. $\mathrm{N}$, neural tube. 
殼筋の平滑筋組織では筋繊維が密に配列しているのに対 し (Fig. 2c)，異常貝では，筋繊維間に結合組織が顕著に 発達し，しばしば広範囲にわたって筋繊維が消失し結合 組織や血球に置き換わっている（Fig. 2d）（黒川ら, 1999)。

原因

本病が感染症である可能性が強いことの主な根拠とし て, 異常貝と健常貝の同居飼育, 異常貝の外套膜片（黒 川ら，1999）および血リンパ液（森実ら，2002）を健常 貝に移植または接種することにより，症状の再現がなさ れることが挙げられる。また，血リンパ液を用いた感染 実験では孔径 $0.45 \mu \mathrm{m}$ のメンブレンフィルターで濾過し た異常貝の血リンパ上清を健常貝に接種しても病状が再 現されることから，滤過性病原体による感染症である可 能性が高いと考えられている（反町，2000）。病原体の 存在部位を特定するため, 異常貝の各組織片を健常貝に 移植する試験がおこなわれ，血リンパ上清，外套膜およ び閉殼筋を移植した試験区で病変の再現がなされたこと から, 主にこれらの器官が原因体の存在部位であると確 認された。しかし, それらの器官の電子顕微鏡観察では, 病原体と疑われるものは観察されていない（Nakayasu et al., 2004)。病原体は種々の手法により探索されている が，現在なお特定には至っていない。

\section{診断法}

本病の診断法としては, 測色計を用いて閉殼筋の $\Delta \mathrm{a}$ 值 (赤色度) を測定する方法（森実ら，2001）, 病理組織学 的観察（黒川ら, 1999), 血リンパ血球のギムザ染色に よる観察（前野ら，2001）および病貝血リンパ血球に反 応する単クローン抗体*などが報告されている。組織異 常および血球の形態異常は, 閉殼筋の赤色度が上昇する 以前の病変が軽度な個体でも観察されることが知られて いることから，本病の診断には総合的な検討をおこなう 必要がある。

\section{疾 病 対 策}

アコヤガイ赤変病は, 発生当初からその原因が不明で あり，また被害が大きかったことから，様々な対策が行 われてきた。まず，夏季の高水温期に大量死が発生する こと, 冬季に比較的低水温の環境下にあった貝ほど，そ の後の高水温期の被害が軽いことが疫学調查等で明らか になった。これらの調査は各研究機関で引き続き行われ, 冬季にアコヤガイを $13^{\circ} \mathrm{C}$ 以下の水温で約 2 か月間飼育す ること等により大量死の被害が軽減されることが明らか

\footnotetext{
*伊東ら (2005)：平成17年日本水産学会春季大会講演要旨集. p. 73.
}

となった（岩永ら，2008a）。現在，冬季に比較的低水温 になりやすい漁場でこの方法が用いられている。その後, 本疾病は感染症であると示唆される報告が相次いだ。そ こで，一定期間使用していないまたは未使用の島しょ部 等の隔離された漁場において, 罹病貝の持ち込みを禁止 するなどして病原体を持ち込ませず，かつ，種苗生産稚 貝または天然採苗の稚貝を種苗として養殖することによ り, 本疾病を発生させない方法が導入された。この方法 は, 愛媛県の日振島や福岡県の相島等, 隔離可能な漁場 で現在用いられている。一方, 本疾病の発生前から, 南 方系のベニコチョウガイ Pinctada fucata が, 高水温に強 く, 真珠の巻きが良いとの理由で海外から日本に持ち込 まれ，一部で養殖されていた。その後この貝は，本疾病 に罹患しても死ににくいことが経験的に知られるように なり，疾病対策として大量に日本に輸入された時期が あった。しかし，この貝には生産された真珠の品質が悪 い等の問題があることから，使用は継続されているもの の大量輸入は現時点ではおこなわれていないようである。 さらに, 疾病対策として全国の真珠貝養殖場のほとんど で種苗生産稚貝が使用されるようになった。この種苗生 産稚貝には, 国, 県, 民間企業の研究機関および漁業協 同組合等で表現形質により選抜された，本疾病に抵抗性 のある貝が親具として使用されている（内村，2002；岩 永ら, 2008b ; 青木, 2015)。これらの親貝には, 日本産 のアコヤガイや上述のベニコチョウガイ等があり, これ らから選抜日本貝や選抜交雑貝が生産されて効果を上げ ている。しかし，選抜貝においてもアコヤガイ赤変病の 症状を示す個体が確認されることから（小田原ら, 2011), アコヤガイのモニタリング調査や選抜育種等の疾 病対策, 病原体の探索等の取り組みを今後も継続する必 要がある。

\section{残された課題}

対策としては, 人工選抜貝の利用により疾病被害は激 減し, 真珠生产量も近年, 回復基調にある。真珠貝の養 殖現場が疾病発生以前の隆盛を取り戻す日も近い。関係 者の不断の努力の成果である。一方，2007年および2008 年に実施された西日本の主要産地である愛媛, 三重, 長 崎および大分県の養殖場に天然アコヤガイを垂下すると いう研究では, 1990年代後半と同様の高い死亡率と病状 が観察され，本病の病原体は養殖場に定着し，現在も存 在していることが示されていることから，今後も注意が 必要である (小田原ら, 2011)。

また, 我々は本邦最大の魚病被害をもたらした病原体 を特定し，その姿を見ることはできていない。病原体の 特定が残された最も大きな課題である。 


\section{文献}

青木秀夫（2015）：高品質アコヤガイ真珠の効率的養殖技術の開 発と実用化. 日水誌, 81, 788-791.

岩永俊介・鈴木正昭・森洋治・塚原淳一郎・細川秀毅 (2008a)：長崎県におけるアコヤガイ母貝養殖場の冬季水 温による感染症軽減効果. 水産增殖, 56, 351-357.

岩永俊介・桑原浩一・細川秀毅（2008b）：アコヤガイの血清夕 ンパク質含量を指標とした優良親貝の選抜．水産増殖， 56, 453-461.

黒川忠英 · 鈴木 徹 - 岡内正典 · 三輪 理 - 永井清仁 - 中村弘 二・本城凡夫・中島員洋・芦田勝朗・船越将二 (1999)： 外套膜移植および同居飼育によるアコヤガイ Pinctada fucata martensii. の閉殼筋の赤変化を伴う疾病の人為的感 染. 日水誌, 65, 241-251.

前野幸男 ·伊東尚史 ·釜石 隆・森実庸男 - 中島員洋 (2001)： 大量死を伴う異常アコヤガイの血球像の変化. 魚病研究, 36, 225-230.

Miyazaki, T., K. Goto, T. Kobayashi, T. Kageyama and M. Miyata (1999): Mass mortalities associated with a virus disease in Japanese pearl oyster Pinctada fucata martensii. Dis. Aquat. Organ., 37, 1-12.
森実庸男・滝本真一・西川 智・松山紀彦・蝶野一徳・植村作 次郎 - 藤田慶之 · 山下浩史 · 川上秀昌 - 小泉喜嗣 - 内村祐 之・市川 衛（2001）：愛媛県宇和海における軟体部の赤 変化を伴うアコヤガイの大量へい死. 魚病研究, 36, 207216.

森実庸男 · 山下浩史 · 藤田慶之 · 川上秀昌 · 越智 修 · 前野幸 男 ·釜石 隆 ·伊東尚史 ·栗田 潤 - 中島員洋 - 芦田勝朗 (2002）：血リンパ接種による軟体部の赤変化を伴うアコヤ ガイ疾病の再現. 魚病研究, 37, 149-151.

室賀清邦・乾 靖夫・松里寿彦 (1999)：ワークショップ「貝 類の新しい疾病」. 魚病研究, 34, 219-231.

Nakayasu, C., H. Aoki, M. Nakanishi, H. Yamashita, M. Okauchi, N. Oseko and A. Kumagai (2004): Tissue Distribution of the Agent of Akoya Oyster Disease in Japanese Pearl Oyster Pinctada fucata martensii Fish pathol, 39, 203-208.

小田原和史・山下浩史・曽根謙一・青木秀夫 - 森 京子・岩永 俊介・中易千早・伊東尚史・栗田潤 - 飯田貴次 (2011)：天然アコヤガイを用いたアコヤガイ赤変病の病勢 調查. 魚病研究, 46, 101-107.

反町 稔 (2000) : アコヤガイの大量へい死. 海洋と生物, 22, $39-44$.

内村祐之（2002）：耐病性アコヤガイの作出. 農林水産技術研 究ジャーナル, 25, 16-19. 